\title{
Synthesis, characterization, and antibacterial activity of azodyes incorporated acridine chromophore and their applications in polyester printing
}

\author{
Khalid M. Hassan ${ }^{a, b}$, El-khabiry Shaban ${ }^{c}$, Ghada M. ElHaddad ${ }^{d}$, Asmaa B. Sallam ${ }^{\text {d }}$ and Ibrahim El \\ Sayed $^{\mathrm{d}^{*}}$
}

${ }^{a}$ Electrochemistry Research Laboratory, Physics and Mathematics Engineering Department, Faculty of Electronic Engineering, Menoufia University, Menouf 23952, Egypt

${ }^{b}$ Applied Sciences Department, Higher College of Technology, University of Technology and Applied Sciences - PO Box 74, Al-Khuwair, Postal Code 133, Muscat - Oman

${ }^{c}$ Dyeing, Printing and Textile Auxiliaries Department, Textile Research Division, National Research Centre, 33 El Bohouth st, Dokki, P.O.12622, Giza, Egypt

${ }^{d}$ Chemistry Department, Faculty of Science, Menoufia University, Shebin El-Kom, Egypt

\begin{tabular}{l}
\hline C H R O N I C L E \\
\hline Article history: \\
Received June 2, 2021 \\
Received in revised form \\
June 18, 2021 \\
Accepted August 31, 2021 \\
Available online \\
August 31, 2021 \\
\hline Keywords: \\
Chloroacridine \\
Amino acridine derivatives \\
Printing polyester \\
Silk-screen \\
Antibacterial activity
\end{tabular}
\begin{abstract}
A B S T R A C T
A series of azo dyes incorporated acridine chromophore labelled as $8(\mathbf{a}-\mathbf{d}), 10(\mathbf{a}, \mathbf{b}), 12$ and 14 were prepared in very good yields starting from 9-chloroacridine $\mathbf{1}$ followed by amination, diazotization and coupling either with rhodanine analogues $6(\mathbf{a}, \mathbf{b})$ or other coupling partners 9 (a, b), 11 and 13. FT-IR, ${ }^{1} \mathrm{H}-\mathrm{NMR}$, and mass spectroscopic analysis were used to establish the structures of the produced azo dispersed dyes. Moreover, the synthesized azo dyes were used to prepare pastes that were used to print polyester fabric using classic silk-screen printing techniques. The dyes were tested for color strength and fastness properties, and they showed good fastness resistance to washing, rubbing, and perspiration, as well as fastness to sublimation and light. The dyes were further screened for their in vitro antibacterial activity against both Gram (+) and Gram (-) bacterial species. Most of them showed promising activities against these tested organisms.
\end{abstract}

\section{Introduction}

Due to their unique structures, synthetic azo dyes are considered as one of the main class of dyes used in different application such as anticancer, ${ }^{1-4}$ antibacterial,,${ }^{1-3}$ antioxidant, ${ }^{2,5}$ antitumor, ${ }^{6}$ and anti-inflammatory. ${ }^{7}$ The dyeing of different textile fabrics by active biological azo structures are the most widely used class of dyes. ${ }^{8}$ Mono azo dyes based on different heterocyclic amine such as acridine moiety have been developed and the product of this type of dyes has higher strength and becomes brighter than those obtained from aniline. In addition, heterocyclic azodyes coupling component with rhodanine derivatives are very important in industrial and medical applications. ${ }^{9-12}$ Furthermore, acridines bearing rhodanine moiety and azo chromophore are important scaffold in broad spectrum activities in medicinal chemistry due to their diverse biological properties such as antimalarial, ${ }^{13}$ antibacterial, ${ }^{14}$ anticancer and DNA-intercalating agents. ${ }^{15}$ The utilizing of $N$ heterocyclic such as acridine azo compounds allows them to bind with polyester textile fabrics by printing method is a hot point in an antibacterial test. These structures are an advantage by the presence of planner tricyclic fused aromatic system, and one or two flexible substituted pharmacophoric groups at different core position on the acridine skeleton. ${ }^{16}$

* Corresponding author.

E-mail address: ibrahimtantawy@yahoo.co.uk (I. E. Sayed)

(C) 2022 by the authors; licensee Growing Science, Canada doi: $10.5267 /$ j.ccl.2021.009.002 
Dyes could be affected by push-pull effect, which have an electron donor and an electron acceptor that are joined by the dye chromophore. The absorption bands of each dye are usually determined by the donor's capacity to donate electrons and the acceptor's ability to release electrons. ${ }^{17}$

Successful prints are based on many important elements such as the proper selection of dyes or pigments and the amount of dye which are used (colour yielding). ${ }^{18}$ They also depend on the type of thickener which are used, the composition of printing paste, the type of fibre composition and the construction of the fabric which will be printed. ${ }^{19}$ Textile printing is the process for applying colour in artistic design to large volumes of fabrics. We can utilize the printing paste by using dyes or pigments. This paste should be viscous which achieved by natural or synthetic thickener. ${ }^{19}$

The main objectives of the present study are to synthesize and evaluate the antibacterial properties of new hybrids of acridine rhodanine azodye derivatives. Additionally, the applications of these acridine- rhodanine disperse dyes for dyeing polyester fibres were studied.

\section{Results and Discussion}

\subsection{Chemistry}

The synthesis of the target amino acridines (acridin-9-yl) benzene-1,3-diamine 3a or (acridin-9-yl) benzene-1,4diamine $\mathbf{3 b}$ was obtained in very good yields according to the protocol shown in Scheme 1. The 9-chloroacridine $\mathbf{1}$ was reacted with 1,3-phenylenediamine $\mathbf{2 a}$ or 1,4-phenylenediamine $\mathbf{2 b}$ in equimolar ratio using DMF as a solvent in presence of TEA under refluxing condition for (10 -12 hrs.) to afford $\mathbf{3 a}$ and $\mathbf{3 b}$ respectively as outlined in Scheme $\mathbf{1}$.<smiles>Clc1c2ccccc2nc2ccccc12</smiles>

1

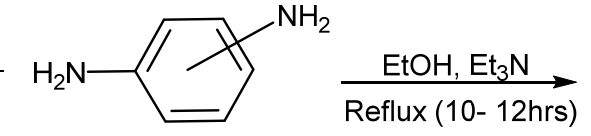

2<smiles>Cc1ccc(Nc2c3ccccc3nc3ccccc23)cc1</smiles>

3a: $3-\mathrm{NH}_{2}-$ b: $4-\mathrm{NH}_{2}-$

Scheme 1. Synthesis of 9 -aminoacridines 3

Moreover, the synthesis of phenolic-rhodanine congers $\mathbf{6 a}, \mathbf{b}$ was executed via Knoevenagel condensation reaction of salicylaldehyde $\mathbf{4}$ with equimolar ratio of rhodanine derivatives $\mathbf{5 a}, \mathbf{b}$ in presence of $\mathrm{AcONa} / \mathrm{AcOH}$ mixture under refluxing condition for $4 \mathrm{hrs}$ as given in Scheme 2.<smiles>O=Cc1ccccc1O</smiles>

4<smiles>[R]N1C(=O)CSC1=S</smiles>

5

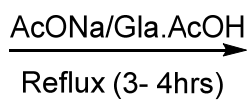

5a: $R=-H$

b: $\mathrm{R}=-\mathrm{CH}_{2}-\mathrm{CH}=\mathrm{CH}_{2}$<smiles>[R]N1C(=O)/C(=C\c2ccccc2O)SC1=S</smiles>

6

Scheme 2. Synthesis of congers 6

The structure elucidations of $\mathbf{6 a}$ showed an analytical data consistence with those reported in the literature..$^{21}$ The structure of $\mathbf{6 b}$ was elucidated by FT-IR, ${ }^{1} \mathrm{H}-\mathrm{NMR}$ and mass spectral techniques. The FT-IR for $\mathbf{6 b}$ shows significant vibration bands at $3228,3050,2924,1680,1588$ and $1205 \mathrm{~cm}^{-1}$ relating to the presence of $(\mathrm{OH}),(=\mathrm{CH}),\left(-\mathrm{CH}_{2}-\right),(-\mathrm{C}=\mathrm{C}-)$, $(\mathrm{C}=\mathrm{O})$ and $(\mathrm{C}=\mathrm{S})$ groups, respectively. The ${ }^{1} \mathrm{H}-\mathrm{NMR}$ characterization of $\mathbf{6 b}$ shows doublets at 4.63 ppm which corresponds to $-\mathrm{CH}_{2}$ - aliphatic, the multiplet at $5.20 \mathrm{ppm}$ relates to the terminal olefinic protons $\left(\mathrm{CH}=\mathrm{CH}_{2}\right)$. The multiplet at 5.83 ppm 
which assigns the internal olefinic proton $\mathrm{C} \underline{\mathrm{H}}=\mathrm{CH}_{2}$, the singlet at $8.07 \mathrm{ppm}$ is related to exocyclic double bond $-\mathrm{C} \underline{\mathrm{H}}=\mathrm{C}<$ and the broad singlet at $10.74 \mathrm{ppm}$ corresponds to the phenolic $(\mathrm{OH})$. Mass spectrum of $\mathbf{6} \mathbf{b}$ confirms the expected molecular ion peak with expected mass unit.

The synthesis of azoacridine derivatives $\mathbf{8}(\mathbf{a}-\mathbf{d}), \mathbf{1 0}(\mathbf{a}, \mathbf{b}), \mathbf{1 2}$ and $\mathbf{1 4}$ requires two components, a diazonium salt and a coupling component. The general synthetic pathway of azo dyes was achieved in two steps; the first step involved reacting 9-aminoacridine derivatives $3 \mathbf{a}, \mathbf{b}$ with conc. $\mathrm{HCl}$ and $\mathrm{NaNO}_{2}$ solution in a crushed ice bath to produce the corresponding non-isolable reactive intermediate, acridine diazonium chloride $7 \mathbf{a}, \mathbf{b}$ as shown in Scheme $\mathbf{3}$.<smiles>Nc1ccc(Nc2c3ccccc3nc3ccccc23)cc1</smiles>

3<smiles></smiles>

7

b: $4-\mathrm{NH}$

7a: $3-\stackrel{+}{\mathrm{N}} \equiv \mathrm{N} \mathrm{Cl}$

b: $4-\stackrel{+}{\mathrm{N}} \equiv \mathrm{N} \mathrm{Cl}$

Scheme 3. Synthesis of diazonium salts 7

The second step includes the reacting of the diazonium salt $\mathbf{7} \mathbf{a}, \mathbf{b}$ (an electrophilic component) with a coupling agent rich in electrons such as $6(\mathbf{a}, \mathbf{b}), 9(\mathbf{a}, \mathbf{b}), 11$ and 13 under basic conditions to yield the azo-dye compounds 8 (a-d), 10 (a, b), 12 and 14 in very good yields as given in Schemes 4 and 5 .

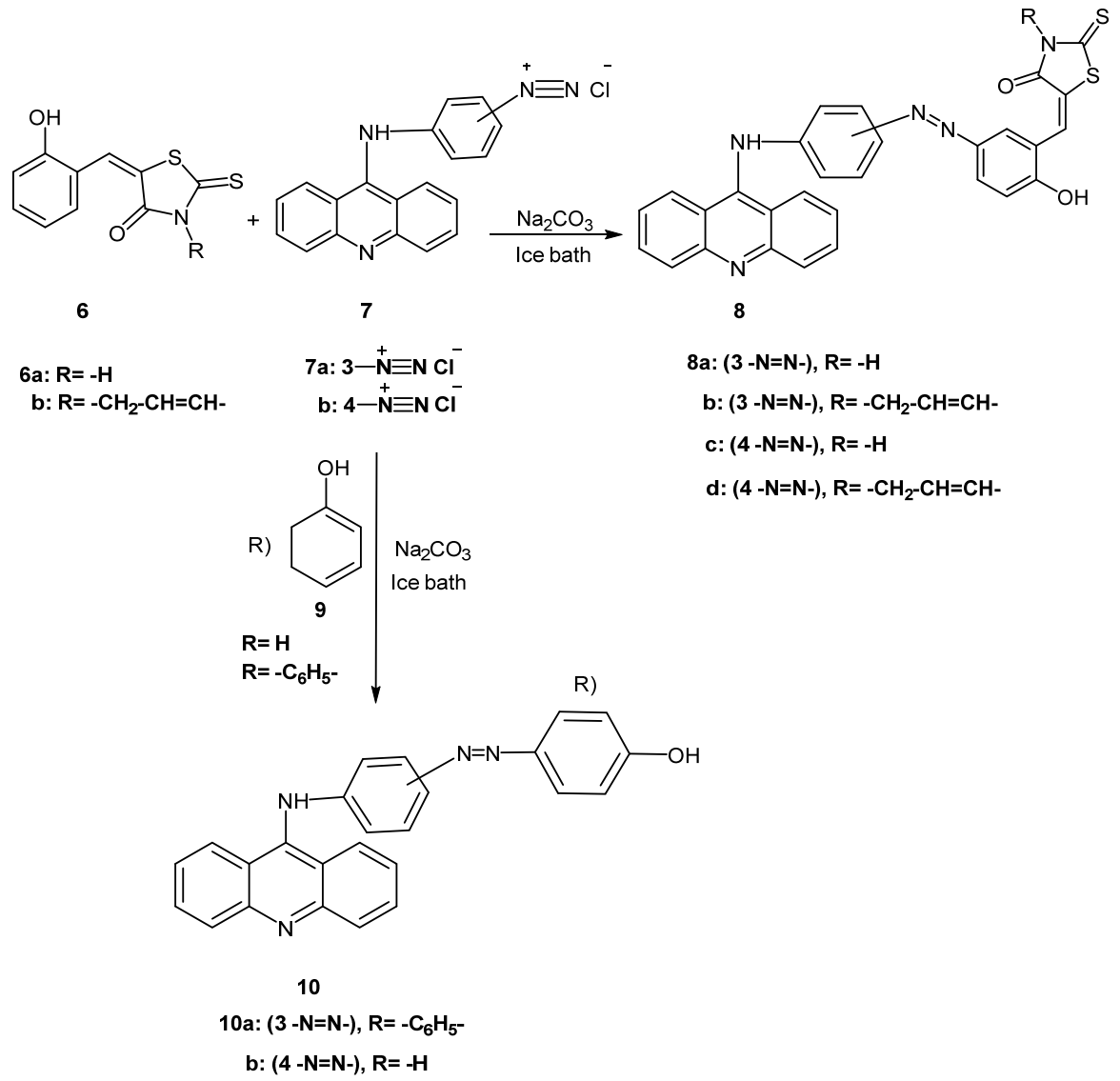

Scheme 4. Synthesis of azoacridine derivatives $\mathbf{8}$ and $\mathbf{1 0}$ 


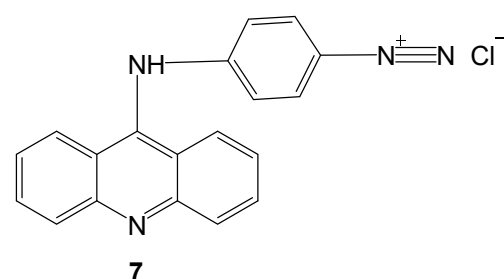

7b: $4-\stackrel{+}{\mathrm{N}} \equiv \mathrm{N} \overline{\mathrm{Cl}}$

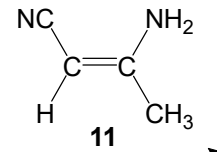

$\mathrm{Na}_{2} \mathrm{CO}_{3}$, Ice bath<smiles>C/C(N)=C(\C#N)N=Nc1ccc(Nc2c3ccccc3nc3ccccc23)cc1</smiles>

12

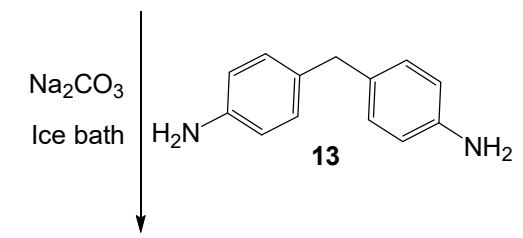<smiles>Nc1ccc(Cc2ccc(N)c(/N=N/c3ccc(Nc4c5ccccc5nc5ccccc45)cc3)c2)cc1</smiles>

Scheme 5. Synthesis of azoacridine derivatives $\mathbf{1 2}$ and $\mathbf{1 4}$

The structure of azocompounds 8 (a-d), $10(\mathbf{a}, \mathbf{b}), 12$ and 14 were elucidated by FT-IR, ${ }^{1} \mathrm{H},{ }^{13} \mathrm{C}-\mathrm{NMR}$ and mass spectral spectroscopic techniques. The FT-IR spectra for $\mathbf{8}$ (a-d) shows a characteristic OH broad band ranged from 3706 to 3073 $\mathrm{cm}^{-1}$, respectively. The $\mathrm{NH}$ group for 8 a-d exhibits characteristic broad bands at $3355,3340,3448$ and $3276 \mathrm{~cm}^{-1}$, respectively. Furthermore, the olefinic $(\mathrm{CH}=\mathrm{C})$ for $\mathbf{8}$ a-d shows absorption bands at 3096, 3096, 3034 and $3049 \mathrm{~cm}^{-1}$, respectively. In addition, the carbonyl $(>\mathrm{C}=\mathrm{O})$ group for them shows absorption band ranging from $1636,1636,1633$ and $1682 \mathrm{~cm}^{-1}$, respectively. Moreover, the azo $(-\mathrm{N}=\mathrm{N}-)$ group shows characteristic bands at $1473,1475,1477$ and $1474 \mathrm{~cm}^{-1}$, respectively while the $(\mathrm{C}=\mathrm{S})$ shows characteristic bands at $1159,1205,1213$ and $1205 \mathrm{~cm}^{-1}$, respectively. ${ }^{1} \mathrm{H}-\mathrm{NMR}$ indicates doublet at $4.65 \mathrm{ppm}$ which corresponds to $\left(-\mathrm{CH}_{2}\right)$ aliphatic for $\mathbf{8 b}$ and $\mathbf{8 c}$. Moreover, multiplet appear at 5.18 and $514 \mathrm{ppm}$ which assigns terminal olefinic protons $\left(-\mathrm{CH}=\mathrm{CH}_{2}\right)$. In addition, multiplet appear at 5.82 and 5.85 ppm which relate to internal olefinic protons $\left(-\mathrm{C} \underline{H}=\mathrm{CH}_{2}\right)$. Furthermore, singlet appears at 7.73, 8.12, 8.12 and 8.14 ppm for $(-\mathrm{C} \underline{H}=\mathrm{C})$ exocyclic double bond for 8a-d, respectively. On the other hand, NH appears at 9.45 and $10.85 \mathrm{ppm}$ for $\mathbf{8 c}$ and $\mathbf{8 d}$, respectively. While the $\mathrm{OH}$ phenolic proton for $\mathbf{8}$ a-d displayed a broad singlet at $11.73,11.75,1175$ and $11.75 \mathrm{ppm}$, respectively. The ${ }^{13} \mathrm{C}$ NMR shows signals at $176.77,176.75,176.26$ and 176.76 ppm corresponding to $>C=\mathrm{O}$ while $>C=S$ group exhibits signals at 193.50, 193.7, 197.87 and 193.53 ppm for $\mathbf{8 a}, \mathbf{8 b}, \mathbf{8 c}$ and $\mathbf{8 d}$, respectively.

The FT-IR spectra for $\mathbf{1 0}(\mathbf{a}, \mathbf{b})$ azocompounds shows a characteristic OH broad band ranging from 3691 to $2735 \mathrm{~cm}^{-1}$. The NH characteristic bands appear at 3427 and $3397 \mathrm{~cm}^{-1}$ for $\mathbf{1 0 a}$ and $\mathbf{1 0 b}$, respectively. While the olefinic $(\mathrm{C}=\mathrm{C})$ and azo groups show characteristic bands for $\mathbf{1 0}$ a and $\mathbf{b}$ at 1587 and $1558 \mathrm{~cm}^{-1}$, respectively. The ${ }^{1} \mathrm{H}-\mathrm{NMR}$ for 10a shows singlet at $10.07 \mathrm{ppm}$ corresponding to proton of $\mathrm{NH}$ group. While broad phenolic $\mathrm{OH}$ proton for $\mathbf{1 0 a}$ and $\mathbf{1 0 b}$ appears at 11.20 and $10.85 \mathrm{ppm}$, respectively. The ${ }^{13} \mathrm{C}-\mathrm{NMR}$ for $\mathbf{1 0 a}$ and $\mathbf{1 0 b}$ shows signals which matches with the expected structures.

The FT-IR spectra for 12 azo compound shows characteristic bands at 3412, 2926, 2185, 1558, 1500 and $1416 \mathrm{~cm}^{-1}$ corresponding to $(\mathrm{NH}),\left(-\mathrm{CH}_{3}\right),(\mathrm{CN}),(\mathrm{C}=\mathrm{C}),(\mathrm{C}=\mathrm{N})$ and $(\mathrm{N}=\mathrm{N})$ groups, respectively. The ${ }^{1} \mathrm{H}-\mathrm{NMR}$ for 12 indicates singlet at $2.19 \mathrm{ppm}$ corresponding to protons of $\left(-\mathrm{CH}_{3}\right)$ aliphatic. Moreover, the broad $2 \mathrm{NH}$ appeared at 9.25 and $10.84 \mathrm{ppm}$. The ${ }^{13} \mathrm{C}$-NMR for 12 shows signal at $24.50 \mathrm{ppm}$ corresponding to the aliphatic carbon $\left(\mathrm{CH}_{3}\right)$ and signals appear at 117.40 and 189.94 corresponding to the carbons of $\mathrm{CN}$ and $\mathrm{C}=\mathrm{C}$, respectively.

The FT-IR spectra for 14 azo compound shows characteristic bands at 3421, 2920, 1558, 1514 and $1476 \mathrm{~cm}^{-1}$ for $(-\mathrm{NH})$, $\left(\mathrm{CH}_{2}\right)$ aliphatic, $(\mathrm{C}=\mathrm{C}),(\mathrm{C}=\mathrm{N})$ and $(\mathrm{N}=\mathrm{N})$ groups, respectively. The ${ }^{1} \mathrm{H}-\mathrm{NMR}$ for 14 appears singlet at $3.71 \mathrm{ppm}$ corresponding to $\left(-\mathrm{CH}_{2}\right)$ aliphatic group. Furthermore, the broad singlet $2 \mathrm{NH}$ appears at 5.34 and $7.50 \mathrm{ppm}$. The ${ }^{13} \mathrm{C}-\mathrm{NMR}$ for 14 shows signals which matches with the expected structure.

The mass spectral analysis for all products $8(\mathbf{a}-\mathbf{d}), \mathbf{1 0}(\mathbf{a}, \mathbf{b}), \mathbf{1 2}$ and 14 shows the expected molecular ion peaks, which confirms the chemical structures. 


\subsection{Colour strength assessments and analyses}

\subsubsection{Colour measurements}

Table 1 shows the results of a light reflectance technique used to test the colour strength data of the printed polyester fabric using a Perkin-Elmer UV/Vis spectrophotometer. ${ }^{34}$

The colour strength (K/S) was calculated as follows: Kubelka-Munk Eq. (1).

$$
\mathrm{K} / \mathrm{S}=\frac{(1-R)^{2}}{2 R}
$$

where $R$ is the decimal fraction of the dyed fabric reflection, K denotes the absorption coefficient, and $S$ denotes the scattering coefficient.

Table. 1. Colour measurements of the printed dyes samples

\begin{tabular}{ccccccccc}
\hline Dye & Colour & Absorption $\lambda_{\max }(\mathbf{n m})$ & $\mathbf{K} / \mathbf{S}$ & $\mathbf{L}^{*}$ & $\mathbf{a}^{*}$ & $\mathbf{b}^{*}$ & $\mathbf{C}^{*}$ & $\mathbf{h}^{*}$ \\
\hline $\mathbf{8 a}$ & Yellow & 360 & 16.36 & 41.02 & 29.50 & 33.96 & 44.98 & 49.02 \\
$\mathbf{8 b}$ & Yellow & 380 & 20.90 & 53.26 & 12.86 & 40.90 & 42.88 & 72.55 \\
$\mathbf{8 c}$ & Yellow & 370 & 12.14 & 57.46 & 14.88 & 43.60 & 46.07 & 71.15 \\
$\mathbf{8 d}$ & Yellow & 365 & 15.14 & 36.93 & 20.23 & 28.51 & 34.96 & 54.65 \\
$\mathbf{1 0 a}$ & Yellow & 375 & 13.36 & 59.53 & 13.52 & 37.78 & 40.13 & 70.31 \\
$\mathbf{1 0 b}$ & Dark yellow & 425 & 22.58 & 46.56 & 12.78 & 29.17 & 31.85 & 66.34 \\
$\mathbf{1 2}$ & Yellow & 365 & 11.30 & 37.28 & 22.68 & 34.14 & 35.18 & 54.80 \\
$\mathbf{1 4}$ & Brown & 410 & 15.56 & 52.35 & 15.97 & 42.06 & 44.99 & 69.21 \\
\hline
\end{tabular}

Lightness ( $\left.\mathrm{L}^{*}\right)$, degree of redness (+ve) and greenness (-ve) (a*), degree of yellowness (+ve) and blueness (-ve) (b*), chroma $\left(\mathrm{c}^{*}\right)$, hue $(\mathrm{h})$ and color strength $(\mathrm{K} / \mathrm{S})$

In our study, the $\mathrm{K} / \mathrm{S}$ values for the dispersed dyes; 8 (a-d), 10 (a, b), 12 and 14 was determined by using their corresponding wavelengths; $360,380,370,365,375,425,365$ and $410 \mathrm{~nm}$, respectively as shown in Table 1. These results indicate the depth of dyes which is proportional to the presented quantity of colorant in the dyed fabrics ${ }^{35}$. The K/S of 10b equal 22.58 is higher than other azo printed dyes due to its higher absorbance value (425) than other printed dyes 8 (a-d), 10 a and 12. The chroma (saturation) $\left(\mathrm{c}^{*}\right)$ and hue angle $\left(\mathrm{h}^{\circ}\right)$ were determined using the equations 2 and 3 according to the reference. ${ }^{36}$

$$
\begin{aligned}
& c^{*}=\sqrt{\left(a^{*}\right)^{2}+\left(b^{*}\right)^{2}} \\
& h=\tan ^{-1}\left(\frac{a^{*}}{b^{*}}\right)
\end{aligned}
$$

The hues angels $\left(\mathrm{h}^{\circ}\right)$ of the printed dyes $8(\mathbf{a}-\mathbf{d}), \mathbf{1 0}(\mathbf{a}, \mathbf{b}), 12$ and 14 were shifted towards the reddish direction due to the positive values of $a^{*}$. Also, they were shifted to the yellowish direction due to the positive values of $b^{*}$ as depicted in Table 1.

\subsubsection{Fastness to washing}

The fastness to washing refers to the ability of dyed fabrics to maintain their colour after being washed at $60{ }^{\circ} \mathrm{C}$ for 30 min with detergents and soaps. The colour change of the printed fabrics and staining is measured accordance to grey scale (1, poor; 2, moderate; 3 , good; 4; very good; 5, excellent). The dyed printed samples $\mathbf{8}$ (a-d), 10 b and $\mathbf{1 4}$ showed moderate to excellent (2-5) results while the dyed printed samples 10a and 12 showed very good to excellent (4-5) results as presented in Table 2. This is because 10 and 12 penetrate and diffuse well into the fiber structure, preventing the dye molecule from reaching the fiber surface. ${ }^{37}$

\subsubsection{Fastness to perspiration}

Fastness to perspiration refers to the dyed fabric's ability to resist fading and staining when perspired. The colour change in acidic and alkaline medium is determined by grey scale. The printed samples 8 (a-d), 10 (a, b), 12 and 14 displayed 
moderate to excellent results (2-5) as shown in Table 2. This due to the higher the molecular weight of the printed dyes which affect the rate of dye removal according to perspiration solution influence. ${ }^{38} 2.2 .4$. Fastness to rubbing

The amount of colour transfer from a dyed fabric surface to an adjacent, undyed fabric surface during rubbing is referred to as fastness to rubbing. It is detected according to the standard grey scale (1-5). The printed samples 8 (a-d), 10 a and 14 showed moderate to excellent results (2-5) while the printed samples $\mathbf{1 0 b}$ and $\mathbf{1 2}$ showed very good to excellent results (45) as given in Table 2. This is the due to the high diffusion of dyes $\mathbf{1 0 b}$ and $\mathbf{1 2}$ molecules into the fiber than other dyes $\mathbf{8}$ (a-d), 10a and 14. ${ }^{39,40}$

\subsubsection{Fastness to light}

Fastness to light refers to how resistant to fading it is when exposed to light. It detected according to the blue scale (18) as (1: very poor, 8: excellent). The printed samples $\mathbf{8}$ (a-d) and $\mathbf{1 2}$ assigned good to very good results (5-6) while the printed samples $\mathbf{1 0}$ a, b and $\mathbf{1 4}$ displayed excellent results (7) as presented in Table $\mathbf{2}$. This is due to the presence of electrondonating groups in $\mathbf{8}(\mathbf{a}-\mathbf{d})$ and $\mathbf{1 2}$ reduces the brightness attributes. ${ }^{41}$

Table 2. Fastness properties of the printed dyes 8 (a-d), 10 (a, b), 12 and 14

\begin{tabular}{|c|c|c|c|c|c|c|c|}
\hline \multirow[t]{2}{*}{ Sample } & \multirow[t]{2}{*}{ Light } & \multicolumn{2}{|c|}{ Washing ${ }^{\text {a) }}$} & \multicolumn{2}{|c|}{ Rubbing } & \multicolumn{2}{|c|}{ Perspiration $^{\text {a) }}$} \\
\hline & & St. & Alt. & Wet & Dry & St. & Alt. \\
\hline $8 \mathbf{a}$ & 6 & $3-4$ & $3-4$ & $2-3$ & $3-4$ & $3-4$ & $4-5$ \\
\hline $8 b$ & 5 & $3-4$ & $3-4$ & $2-3$ & $3-4$ & $3-4$ & $4-5$ \\
\hline $8 c$ & 6 & $3-4$ & $4-5$ & 4 & $2-3$ & $3-4$ & $3-4$ \\
\hline $8 d$ & 6 & $4-5$ & $2-3$ & $3-4$ & $4-5$ & $2-3$ & $2-3$ \\
\hline $10 a$ & 7 & $4-5$ & $4-5$ & $3-4$ & 4 & $4-5$ & 4 \\
\hline $10 b$ & 7 & 4 & $3-4$ & $4-5$ & $4-5$ & $4-5$ & $4-5$ \\
\hline 12 & 5 & $4-5$ & $4-5$ & $4-5$ & $4-5$ & $3-4$ & $4-5$ \\
\hline 14 & 7 & $3-4$ & $3-4$ & $3-4$ & 4 & $3-4$ & 4 \\
\hline
\end{tabular}

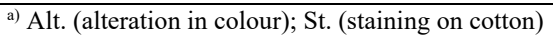

\subsubsection{Fastness to sublimation}

Fastness to sublimation refers to the printed dyes' ability to resist high temperatures and pressure. It was detected according to the standard grey scale. The printed dyes samples assigned moderate to excellent results (2-5) as depicted in Table 3. This is due to the polarity of the substituent groups which presented in the printed dyes such as $\mathrm{OH}$ and $\mathrm{NH}$ groups. $^{42}$

Table 3. Sublimation properties of the printed dyes 8 (a-d), 10 (a, b), 12 and 14

\begin{tabular}{|c|c|c|c|c|}
\hline \multirow[t]{2}{*}{ Sample } & \multicolumn{2}{|c|}{ Sublimation fastness } & \multicolumn{2}{|c|}{ Staining on fabric after sublimation } \\
\hline & $180^{\circ} \mathrm{C}$ & $210^{\circ} \mathrm{C}$ & Polyester & Cotton \\
\hline $8 \mathbf{8}$ & $4-5$ & $4-5$ & $3-4$ & 4 \\
\hline $\mathbf{8 b}$ & 4 & $3-4$ & $3-4$ & $3-4$ \\
\hline $8 c$ & 4 & $3-4$ & 4 & $3-4$ \\
\hline 8d & $4-5$ & $2-3$ & $3-4$ & $2-3$ \\
\hline $10 \mathbf{a}$ & $4-5$ & $4-5$ & $3-4$ & $3-4$ \\
\hline $10 b$ & $4-5$ & $4-5$ & $4-5$ & $4-5$ \\
\hline 12 & 4 & $2-3$ & $3-4$ & $2-3$ \\
\hline 14 & $4-5$ & 4 & $4-5$ & $3-4$ \\
\hline
\end{tabular}

\subsection{Antibacterial screening}

The study of biological activities of acridine- rhodanine hybrid compounds containing azo dye is of great interest to explore the synthesis of new and potentially useful product. Table 4 illustrates the outcomes of four washing of polyester fabrics dyed with freshly synthetic dyes. It means the starting material (1) has poor antibacterial activity, with inhibition zones ranging from 9 to $12 \mathrm{~mm}$. The polyester which loaded with azo dye $8 \mathbf{c}$ compound showed a good activity and was found to be highly active against both Gram (+) and Gram (-) bacteria among all tested samples followed by polyester loaded with 14 with inhibition zone ranging of (10-16) mm than $\mathbf{8}(\mathbf{a}, \mathbf{b}), \mathbf{1 0}(\mathbf{a}, \mathbf{b})$ and $\mathbf{1 2}$ compounds with inhibition zone ranging of (9-14) $\mathrm{mm}$. Therefore, by evaluating data analysis obtained highlighted that, for the novel acridine-rhodanine hybrid analogues containing azo dyes printed samples 8 (a-d), 10 (a, b), 12 and 14 when compared to the reference medication Ampicillin, it displayed a broad spectrum of antibacterial activity with different inhibition zones. The azo compound $8 \mathbf{c}$ had the best antibacterial activity against $\mathrm{S}$. aureus with inhibition zone of $16 \mathrm{~mm}$ which is similar to the inhibition zone of $21 \mathrm{~mm}$ of the reference medication Ampicillin. 
The capability of newly produced azo dyes to attach to the bacterial cell wall and cytoplasmic membrane may explain their inhibitory effect, followed by a change in selective permeability function, leading in cellular component leakage, as a result , bacterial death ${ }^{43}$. Toxic effects are also caused by the synthesis of new azo-cleaved compounds such as amines produced by azo dyes being entered into bacterial cells. Furthermore, by reacting with the thiol group, the newly synthesized compounds can inhibit bacterial growth by inactivating protein synthesis ${ }^{44}$ or by interacting with phosphorus moieties to stop DNA replicationt. ${ }^{45}$

Table 4. Antibacterial activity for the printed dyes against Gram (+) and Gram (-) bacteria after 4 washing cycles

\begin{tabular}{|c|c|c|c|c|c|c|c|}
\hline \multirow{3}{*}{\multicolumn{2}{|c|}{ Compounds }} & \multicolumn{6}{|c|}{ Inhibition zone diameter (mm) } \\
\hline & & \multicolumn{3}{|c|}{ Gram (+) } & \multicolumn{3}{|c|}{ Gram (-) } \\
\hline & & B. subtilis & S. saureus & S. faecalis & E. coli & N. gonorrhoeae & P. aeruginosa \\
\hline \multicolumn{2}{|c|}{ Ampicillin } & 26 & 21 & 27 & 25 & 28 & 26 \\
\hline \multicolumn{2}{|c|}{1} & 12 & 12 & 9 & 12 & 9 & - \\
\hline \multicolumn{2}{|c|}{ Untreated polyester } & - & - & - & - & - & - \\
\hline \multirow{8}{*}{ 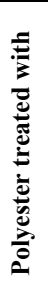 } & $8 a$ & 12 & 12 & 9 & 13 & 11 & 11 \\
\hline & $8 b$ & 11 & 12 & 10 & 13 & 10 & 10 \\
\hline & $8 c$ & 13 & 16 & 15 & 15 & 14 & 14 \\
\hline & $8 d$ & 13 & 12 & 11 & 13 & 12 & 12 \\
\hline & $10 a$ & 9 & - & 9 & 10 & 9 & - \\
\hline & 10b & 13 & 9 & 12 & 14 & 12 & 12 \\
\hline & 12 & 14 & 10 & 13 & 13 & 12 & 11 \\
\hline & 14 & 12 & 10 & 10 & 12 & 11 & 10 \\
\hline
\end{tabular}

\section{Conclusions}

New acridine derivatives incorporated azo dispersed dyes were synthesized, characterized, and evaluated in very good yields. The dyes were applied in polyester fabric printing using traditional silk screen printing. Moreover, the fastness properties and colour measurement of printed samples showed moderate to excellent results (2-5) towards washing, rubbing, perspiration and sublimation fastness properties comparing with grey scale (1-5), while good to excellent results (5-7) towards light fastness comparing with blue scale (1-8). The in vitro antibacterial screening of the starting compound (9chloroacridine) (1) showed low antibacterial activity than printed azo disperse dyes which showed moderate activity with inhibition zones ranging from 9 to $16 \mathrm{~mm}$ towards Gram (+) and Gram (-) bacteria strains with the reference drug, ampicillin.

\section{Experimental}

\subsection{Materials and Methods}

The ${ }^{1} \mathrm{H}$ - and ${ }^{13} \mathrm{C}-\mathrm{NMR}$ measurements were obtained on a JEOL ECA500 FT NMR spectrometer at $500 \mathrm{MHz}$ and 100 $\mathrm{MHz}$, respectively. ${ }^{1} \mathrm{H}-\mathrm{NMR}$ samples were measured with $400 \mathrm{MHz}$ Varian. Dimethyl sulfoxide (DMSO-d ${ }_{6}$ ) was used as solvent for all NMR measurements. Chemical shift $(\delta)$ was reported in part per million $(\mathrm{ppm})$ on scale. Fourier transform infrared (FT-IR) spectra were recorded using Thermo Fisher Nicolet IS10, Spectral Analyses Unit. The electron impact ionization (EI-MS) was carried on a Thermos Scientific Trace 1310 Mass Spectrometry. UV/Vis absorption spectra for azo compounds were measured by Perkin-Elmer UV/Vis spectrophotometer (Model, Lambda 3B). The in vitro antibacterial activity analysis was carried out at Micro Analytical Center, Cairo University, Egypt. The melting points (m.p) were measured by Stuart scientific melting point apparatus and were uncorrected. Thin layer chromatography (TLC) was performed for all synthetized products on kiesel gel F254 precoated plates (Merck) Solvents such as ethanol, methanol, dichloromethane, hexane, dimethylformamide and diethyl ether were used as received without further purification. The starting materials were either commercially available as 9-Chloroacridine (99.0\%), 1,3-phenylenediamine (99.0\%), 1,4phenylenediamine $(99.0 \%)$, rhodanine $(97.0 \%)$, allyl rhodanine $(99.0 \%)$, 3-aminocrotonitrile and 4,4'-methylenedianiline (97.0\%) were bought from Sigma Aldrich. Phenol, $\alpha$-naphthol (99.0\%), salicylaldehyde (99.0\%), triethylamine (TEA) $(99.0 \%)$, ethanol (EtOH) $(99.0 \%)$, concentrated hydrochloric acid (Conc. $\mathrm{HCl})(35.4 \%)$, glacial acetic acid $(\mathrm{Gla} . \mathrm{AcOH})$ (99.7\%), dichloromethane (DCM) $(99.8 \%)$, dimethylformamide (DMF) $(99.0 \%)$, sodium carbonate $\left(\mathrm{Na}_{2} \mathrm{CO}_{3}\right)(98.0 \%)$, sodium nitrite $\left(\mathrm{NaNO}_{2}\right)(98.0 \%)$ and sodium lignosulphonate (dispersing agent) $(99.5 \%)$ were bought from LOBA Chemie. Sodium acetate (AcONa) (99.0\%) was obtained from East-Chem. Thickener (commercial synthetic thickener) acrylate copolymers and Lyprint (sodium salt of nitrobenzene sulfonic acid) were supplied from BASF Company. Polyesters (150 $\mathrm{g} / \mathrm{m}^{2}$ ) were supplied by Egyptian and developing Co., Cairo, Egypt. All chemicals and solvents were used without any further purification using DCM: EtOH (5:1) equivalents as the mobile phase. Compounds 3 (a, b) and 6a were prepared according to literature methods. ${ }^{20-22}$ 


\subsection{General procedure}

\subsubsection{General method for rhodanine analogues 6}

Condensation of salicylaldehyde (labelled as 4) $(0.42 \mathrm{~mL}, 4 \mathrm{mmol})$ with rhodanine $\mathbf{5 a}(0.95 \mathrm{gm}, 4 \mathrm{mmol})$ or allyl rhodanine $5 \mathbf{a}(0.69 \mathrm{gm}, 4 \mathrm{mmol})$ were dissolved in $(\mathrm{Gla}$. $\mathrm{AcOH})$ in presence of $\mathrm{AcONa}(0.33 \mathrm{gm}, 12 \mathrm{mmol})$. The reaction mixture was refluxed for $(3: 4 \mathrm{hrs}$.) until the starting materials were consumed. The progress of the reaction was checked by TLC using the mixture of DCM: EtOH (5:1) as eluent. After completion of the reaction, the mixture was cooled and poured portion-wise into ice-cold water and the precipitated solid was filtered off, washed several times, recrystallized using EtOH and dried in air to afford products $6(\mathbf{a}, \mathbf{b})$.

\subsubsection{Synthesis of 9-azoacridine disperse dyes $8,10,12 \& 14$}

\subsubsection{Preparation of diazonium salt 7}

Amine analogues (acridin-9-yl) benzene-1,3-diamine 3a or (acridin-9-yl) benzene-1,4-diamine 3b (0.285 gm, $1.0 \mathrm{mmol})$ were mixed with conc. $\mathrm{HCl}(4.0 \mathrm{~mL}, 35.4 \%)$ in glass beaker $(25.0 \mathrm{~mL})$ under constant stirring at below $5^{\circ} \mathrm{C}$ in an ice bath. $\mathrm{NaNO}_{2}$ solution $(0.069 \mathrm{gm}, 1.0 \mathrm{mmol})$ in water $(3.0 \mathrm{~mL})$ was slowly added to obtain diazonium salt $7(\mathbf{a}, \mathbf{b})$.

\subsubsection{General procedure of coupling}

The produced diazonium salt 7 (a, b) was stirred for an extra $30 \mathrm{~min}$ at $0-5{ }^{\circ} \mathrm{C}$. In another glass beaker $(25.0 \mathrm{~mL})$, rhodanine analogues $6(\mathbf{a}, \mathbf{b})$ modified at C-5 position or other coupling partners $9(\mathbf{a}, \mathbf{b}), \mathbf{1 1}$, or $\mathbf{1 3}(1.0 \mathrm{mmol})$ was dissolved in ethanol $(5.0 \mathrm{~mL})$ and $\mathrm{Na}_{2} \mathrm{CO}_{3}(1.0 \mathrm{gm}, 10.0 \mathrm{mmol})$ was added. The reaction mixture was stirred in the ice bath below 5 ${ }^{\circ} \mathrm{C}$. The obtained clear diazonium salt solution was added immediately drop by drop in coupling reactions with coupling partners $\mathbf{6}(\mathbf{a}, \mathbf{b}), 9(\mathbf{a}, \mathbf{b}), \mathbf{1 1}$, or 13. The mixture was stirred for $2 \mathrm{hrs}$. The final product was collected by filtration under vacuum, washed several times with distilled water and finally air-dried to obtain the azo compounds 8 (a-d), 10 (a, b), 12 and $\mathbf{1 4}$ in very good yields.

\subsection{Physical and Spectral Data}

2-(2-Hydroxybenzylidene)-5-thioxodihy drothiophen-3(2H)-one (6b)

Yellowish powder; yield $(0.81 \mathrm{~g}, 81 \%)$; m.p $\left(148-150^{\circ} \mathrm{C}\right)$; FT-IR $(\mathrm{KBr})\left(\mathrm{cm}^{-1}\right)=3228(\mathrm{OH}), 3050(=\mathrm{CH}), 2924\left(-\mathrm{CH}_{2}-\right)$, $1680(\mathrm{C}=\mathrm{O}), 1588(\mathrm{C}=\mathrm{C}), 1205(\mathrm{C}=\mathrm{S}) .{ }^{1} \mathrm{H}-\mathrm{NMR}\left(\mathrm{DMSO}-\mathrm{d}_{6}, \mathrm{ppm}\right): \delta=4.63\left(\mathrm{~m}, 2 \mathrm{H}, \mathrm{CH}_{2}=\mathrm{CH}\right), 5.20(\mathrm{~m}, 2 \mathrm{H}, \mathrm{CH}=\mathrm{CH} 2)$, $5.83\left(\mathrm{~m}, 1 \mathrm{H}, \mathrm{CH}=\mathrm{CH}_{2}\right), 6.95-7.73\left(\mathrm{~m}, 4 \mathrm{H}, \mathrm{CH}_{\mathrm{Ar}}\right), 8.07$ (s, $\left.1 \mathrm{H}, \mathrm{C} \underline{\mathrm{H}}=\mathrm{C}\right), 10.74$ (br. s, $\left.1 \mathrm{H}, \mathrm{OH}\right) . \mathrm{EI}-\mathrm{MS}(\mathrm{m} / z)\left(\mathrm{C}_{13} \mathrm{H}_{14} \mathrm{NO}_{2} \mathrm{~S}_{2}\right)$ : calcd, 280; found molecular ion peak $279[\mathrm{M}-1]^{+}$.

\section{2-((3-(Acridin-9-ylamino) phenyl) diazenyl)-5-hydroxybenzylidene)-2-thioxothiazolidin-4-one (8a)}

Yellow powder; yield (0.70 gm, $70 \%)$; m.p $\left(188-190^{\circ} \mathrm{C}\right)$; FT-IR $(\mathrm{KBr})\left(\mathrm{cm}^{-1}\right)=3559-3191(\mathrm{OH}), 3355(\mathrm{NH}), 3096(=\mathrm{CH})$, $1636(\mathrm{C}=\mathrm{O}), 1596(\mathrm{C}=\mathrm{C}), 1534(\mathrm{C}=\mathrm{N}), 1473(\mathrm{~N}=\mathrm{N}), 1159(\mathrm{C}=\mathrm{S}) .{ }^{1} \mathrm{H}-\mathrm{NMR}\left(\mathrm{DMSO}-\mathrm{d}_{6}, \mathrm{ppm}\right): \delta=7.23-7.55(\mathrm{~m}, 13 \mathrm{H}$, $\left.\mathrm{CH}_{\mathrm{Ar}}\right), 7.73(\mathrm{~s}, 1 \mathrm{H}, \mathrm{C} \underline{\mathrm{H}}=\mathrm{C}), 8.42\left(\mathrm{~m}, 2 \mathrm{H}, \mathrm{CH}_{\mathrm{Ar}}\right), 11.73$ (br. s, $\left.1 \mathrm{H}, \mathrm{OH}\right) .{ }^{13} \mathrm{C}-\mathrm{NMR}\left(\mathrm{DMSO}-\mathrm{d}_{6}, 100 \mathrm{MHz}\right) \delta: 116.61,117.61$, $119.78,120.99,121.43,122.54,123.26,124.91,126.79,127.94,128.92,130.27,131.60,133.44,134.49,137.14,140.88$, 142.37, 150.00, 151.89, 158.53, 176.77, 193.50. EI-MS $\left(\mathrm{C}_{28} \mathrm{H}_{19} \mathrm{~N}_{5} \mathrm{O}_{2} \mathrm{~S}_{2}\right)$ : Calcd. (533); found molecular ion peak 532 [M$1]^{+}$.

\section{2-((3-(Acridin-9-ylamino) phenyl) diazenyl)-5-hydroxybenzylidene)-3-allyl-2 thioxothiazolidin-4-one (8b)}

Yellow powder; yield (0.84 gm, 84 \%); m.p $\left(178-180^{\circ} \mathrm{C}\right)$; FT-IR $(\mathrm{KBr})\left(\mathrm{cm}^{-1}\right)=3573-3073(\mathrm{OH}), 3340(\mathrm{NH}), 3096(=\mathrm{CH})$, $2991\left(\mathrm{CH}_{2}\right), 1636(\mathrm{C}=\mathrm{O}), 1595(\mathrm{C}=\mathrm{C}), 1533(\mathrm{C}=\mathrm{N}), 1475(\mathrm{~N}=\mathrm{N}), 1205(\mathrm{C}=\mathrm{S}) .{ }^{1} \mathrm{H}-\mathrm{NMR}\left(\mathrm{DMSO}-\mathrm{d}_{6}, \mathrm{ppm}\right): \delta=4.65(\mathrm{~d}, J=$ $\left.8 \mathrm{~Hz}, 2 \mathrm{H}, \mathrm{CH}_{2}\right), 5.14\left(\mathrm{~m}, 2 \mathrm{H}, \mathrm{CH}=\mathrm{CH}_{2}\right), 5.85\left(\mathrm{~m}, 1 \mathrm{H}, \mathrm{CH}=\mathrm{CH}_{2}\right), 6.97\left(\mathrm{~m}, 2 \mathrm{H}, \mathrm{CH}_{\mathrm{Ar}}\right), 7.23-7.74\left(\mathrm{~m}, 11 \mathrm{H}, \mathrm{CH}_{\mathrm{Ar}}\right), 8.12(\mathrm{~s}$, $1 \mathrm{H}, \mathrm{CH}=\mathrm{C}), 8.35\left(\mathrm{~m}, 2 \mathrm{H}, \mathrm{CH}_{\mathrm{Ar}}\right), 11.75(\mathrm{~s}, 1 \mathrm{H}, \mathrm{OH}) .{ }^{13} \mathrm{C}-\mathrm{NMR}\left(\mathrm{DMSO}-\mathrm{d}_{6}, 100 \mathrm{MHz}\right) \delta: 45.97,115.99,116.20,116.61$, 117.72 , 117.72, 118.82, 119.93, 120.46, 120.97, 121.33, 122.28, 124.79, 125.99, 126.52, 126.78, 128.78, 129.87, 130.35, 131.28, 133.21, 133.42, 140.89, 166.82, 176.75, 193.7. EI-MS $\left(\mathrm{C}_{32} \mathrm{H}_{23} \mathrm{~N}_{5} \mathrm{O}_{2} \mathrm{~S}_{2}\right)$ : Calcd. (573); found molecular ion peak 573 $\left[\mathrm{M}^{+}\right]$.

\section{5-((4-(Acridin-9-ylamino) phenyl) diazenyl)-2-hydroxybenzylidene)-2-thioxothiazolidin-4-one (8c)}

Yellow brown powder; yield (0.75 gm, 75 \%); m.p $\left(136-138^{\circ} \mathrm{C}\right)$; FT-IR $(\mathrm{KBr})\left(\mathrm{cm}^{-1}\right)=3706-3191(\mathrm{OH}), 3448(\mathrm{NH}), 3034$ $(=\mathrm{CH}), 1633(\mathrm{C}=\mathrm{O}), 1590(\mathrm{C}=\mathrm{C}), 1518(\mathrm{C}=\mathrm{N}), 1477(\mathrm{~N}=\mathrm{N}), 1213(\mathrm{C}=\mathrm{S}) .{ }^{1} \mathrm{H}-\mathrm{NMR}\left(\mathrm{DMSO}-\mathrm{d}_{6}, \mathrm{ppm}\right): \delta=6.25(\mathrm{~d}, J=10$ $\left.\mathrm{Hz}, 2 \mathrm{H}, \mathrm{CH}_{\mathrm{Ar}}\right), 6.91-7.71\left(\mathrm{~m}, 11 \mathrm{H}, \mathrm{CH}_{\mathrm{Ar}}\right), 8.12(\mathrm{~s}, 1 \mathrm{H}, \mathrm{CH}=\mathrm{C}), 8.44\left(\mathrm{~m}, 2 \mathrm{H}, \mathrm{CH}_{\mathrm{Ar}}\right), 9.45(\mathrm{~s}, 2 \mathrm{H}, \mathrm{NH}), 11.75(\mathrm{br} . \mathrm{s}, 1 \mathrm{H}$, $\mathrm{OH}) .{ }^{13} \mathrm{C}$ NMR (DMSO-d $\left.6,100 \mathrm{MHz}\right) \delta: 116.60,117.32,118.72,119.78,121.58,122.53,123.77,124.90,125.98,126.77$, 128.94, 130.25, 131.60, 132.76, 133.41, 137.14, 140.88, 149.99, 157.31, 176.26, 197.87. EI-MS $\left(\mathrm{C}_{28} \mathrm{H}_{19} \mathrm{~N}_{5} \mathrm{O}_{2} \mathrm{~S}_{2}\right)$ : Calcd. (533); found while molecular ion peak $533\left[\mathrm{M}^{+}\right]$. 
5-((4-(Acridin-9-ylamino) phenyl) diazenyl)-2-hydroxybenzylidene)-3-allyl-2-thioxothiazolidin-4-one (8d)

Yellow powder; yield (0.80 gm, $80 \%)$; m.p $\left(136-138^{\circ} \mathrm{C}\right)$; FT-IR $(\mathrm{KBr})\left(\mathrm{cm}^{-1}\right)=3662-3118(\mathrm{OH}), 3276(\mathrm{NH}), 3049(=\mathrm{CH})$, $2927\left(-\mathrm{CH}_{2}\right), 1682(\mathrm{C}=\mathrm{O}), 1593(\mathrm{C}=\mathrm{C}), 1516(\mathrm{C}=\mathrm{N}), 1474(\mathrm{~N}=\mathrm{N}), 1205(\mathrm{C}=\mathrm{S}) .{ }^{1} \mathrm{HNMR}\left(\mathrm{DMSO}-\mathrm{d}_{6}, \mathrm{ppm}\right): \delta=4.65(\mathrm{~d}, \mathrm{~J}=$ $\left.8 \mathrm{~Hz}, 2 \mathrm{H}, \mathrm{CH}_{2}\right), 5.18\left(\mathrm{~m}, 2 \mathrm{H}, \mathrm{CH}=\mathrm{CH}_{2}\right), 5.82\left(\mathrm{~m}, 1 \mathrm{H}, \mathrm{CH}=\mathrm{CH}_{2}\right), 6.98\left(\mathrm{~m}, 2 \mathrm{H}, \mathrm{CH}_{\mathrm{Ar}}\right), 7.33-7.99\left(\mathrm{~m}, 11 \mathrm{H}, \mathrm{CH}_{\mathrm{Ar}}\right), 8.14(\mathrm{~s}$, $1 \mathrm{H}, \mathrm{CH}=\mathrm{C}), 8.45\left(\mathrm{~m}, 2 \mathrm{H}, \mathrm{CH}_{\mathrm{Ar}}\right), 10.85$ (br. s, $\left.1 \mathrm{H}, \mathrm{NH}\right), 11.75(\mathrm{~s}, 1 \mathrm{H}, \mathrm{OH}) .{ }^{13} \mathrm{C}-\mathrm{NMR}$ (DMSO-d6,100 MHz) $\delta: 46.00$, $116.62,117.76,119.91,120.99,122.55,123.79,124.92,126.78,127.95,129.68,131.61,133.45,134.49,137.14,140.88$, 142.37, 151.90, 157.63, 158.54, 166.79, 176.76, 193.53. EI-MS $\left(\mathrm{C}_{32} \mathrm{H}_{23} \mathrm{~N}_{5} \mathrm{O}_{2} \mathrm{~S}_{2}\right)$ : Calcd. (573); found molecular ion peak $573[\mathrm{M}+]$.

\section{(4-((3-(Acridin-9-ylamino) phenyl) diazenyl) naphthalen-1-ol (10a)}

Yellow powder; yield (0.69 gm, 69 \%); m.p $\left(288-290^{\circ} \mathrm{C}\right)$; FT-IR $(\mathrm{KBr})\left(\mathrm{cm}^{-1}\right)=3662-2735(\mathrm{OH}), 3427(\mathrm{NH}), 1587(\mathrm{C}=\mathrm{C})$, $1520(\mathrm{C}=\mathrm{N}), 1475(\mathrm{~N}=\mathrm{N}) .{ }^{1} \mathrm{H}-\mathrm{NMR}\left(\mathrm{DMSO}_{\mathrm{d}}\right): \delta=6.82-7.29\left(\mathrm{~m}, 10 \mathrm{H}, \mathrm{CH}_{\mathrm{Ar}}\right), 7.42-8.21\left(\mathrm{~m}, 8 \mathrm{H}, \mathrm{CH}_{\mathrm{Ar}}\right), 10.07(\mathrm{~s}, 1 \mathrm{H}$, $\mathrm{NH}), 11.20(\mathrm{~S}, 1 \mathrm{H}, \mathrm{OH}) .{ }^{13} \mathrm{C}-\mathrm{NMR}\left(\mathrm{DMSO}-\mathrm{d}_{6}, 100 \mathrm{MHz}\right) \delta: 115.90,117.18,118.53,12.86,122.28,126.77,130.14,131.56$, $132.15,132.76,133.80,135.09,136.45,138.42,139.77,141.13,142.10,143.08,145.40,150.76,155.04$. EI-MS $\left(\mathrm{C}_{29} \mathrm{H}_{20} \mathrm{~N}_{4} \mathrm{O}\right)$ : Calcd. (440); found molecular ion peak $440\left[\mathrm{M}^{+}\right]$.

\section{4-((4-(Acridin-9-ylamino) phenyl) diazenyl) phenol (10b)}

Dark yellow powder; yield (0.65 gm, 65\%); m.p $\left(210-212^{\circ} \mathrm{C}\right)$; FT-IR $(\mathrm{KBr})\left(\mathrm{cm}^{-1}\right)=3691-2765(\mathrm{OH}), 3397(\mathrm{NH}) 1558$ $(\mathrm{C}=\mathrm{C}), 1514(\mathrm{C}=\mathrm{N}), 1475(\mathrm{~N}=\mathrm{N}) .{ }^{1} \mathrm{H}-\mathrm{NMR}\left(\mathrm{DMSO}-\mathrm{d}_{6}\right): \delta=6.69-7.72\left(\mathrm{~m}, 10 \mathrm{H}, \mathrm{CH}_{\mathrm{Ar}}\right), 7.47-8.10\left(\mathrm{~m}, 6 \mathrm{H}, \mathrm{CH}_{\mathrm{Ar}}\right), 10.85(\mathrm{br}$. $\mathrm{s}, 1 \mathrm{H}, \mathrm{OH}) .{ }^{13} \mathrm{C}-\mathrm{NMR}\left(\mathrm{DMSO}-\mathrm{d}_{6}, 100 \mathrm{MHz}\right) \delta: 115.89,118.87,119.41,120.18,124.26,127.34,129.16,129.62,130.50$, 131.27, 131.75, 141.43, 141.80, 151.37. EI-MS $\left(\mathrm{C}_{25} \mathrm{H}_{18} \mathrm{~N}_{4} \mathrm{O}\right)$ : Calcd. (390); found molecular ion peak $391[\mathrm{M}+1]^{+}$.

\section{2- ((4-(Acridin-9-ylamino) phenyl) diazenyl)-3-iminobutanenitrile (12)}

Yellow powder; yield (0.69 gm, $69 \%)$; m.p $\left(100-102^{\circ} \mathrm{C}\right)$; FT-IR $(\mathrm{KBr})\left(\mathrm{cm}^{-1}\right)=3412(\mathrm{NH}), 2926\left(-\mathrm{CH}_{3}\right), 2185(\mathrm{CN}), 1558$ $(\mathrm{C}=\mathrm{C}), 1500(\mathrm{C}=\mathrm{N}), 1416(\mathrm{~N}=\mathrm{N}) .{ }^{1} \mathrm{HNMR}\left(\mathrm{DMSO}-\mathrm{d}_{6}\right): \delta=2.19\left(\mathrm{~s}, 3 \mathrm{H}, \mathrm{CH}_{3}\right), 6.65-7.50\left(\mathrm{~m}, 10 \mathrm{H}, \mathrm{CH}_{\mathrm{Ar}}\right), 8.43(\mathrm{~m}, 2 \mathrm{H}$, $\left.\mathrm{CH}_{\mathrm{Ar}}\right) 9.25$ (br. s, $2 \mathrm{H}, \mathrm{NH}_{2}$ ), 10.84 (s, $\left.1 \mathrm{H}, \mathrm{NH}\right) .{ }^{13} \mathrm{C}-\mathrm{NMR}$ (DMSO-d $6,100 \mathrm{MHz}$ ) $\delta: 24.50,109.07,117.40,118.41,120.80$, $122.35,126.83,128.74,129.56,130.29,131.02,134.55,149.33,150.03,189.94$. EI-MS $\left(\mathrm{C}_{23} \mathrm{H}_{18} \mathrm{~N}_{6}\right)$ : Calcd. (378); found molecular ion peak $379[\mathrm{M}+1]^{+}$.

N-(4-((2-Amino-5-(4-aminobenzyl) phenyl) diazenyl) phenyl) acridin-9-amine (14)

Brown powder; yield (0.75 gm, $75 \%$ ); m.p $\left(128-130^{\circ} \mathrm{C}\right)$; FT-IR $(\mathrm{KBr})\left(\mathrm{cm}^{-1}\right)=3421(\mathrm{NH}), 2920\left(\mathrm{CH}_{2}\right), 1558(\mathrm{C}=\mathrm{C}), 1514$ $(\mathrm{C}=\mathrm{N}), 1476(\mathrm{~N}=\mathrm{N}) .{ }^{1} \mathrm{H}-\mathrm{NMR}\left(\mathrm{DMSO}_{\mathrm{d}}\right): \delta=3.71\left(\mathrm{~s}, 2 \mathrm{H}, \mathrm{CH}_{2}\right), 5.34$ (br. s, 4H, NH), 6.43-7.70 (m, $\left.19 \mathrm{H}, \mathrm{CH}_{\mathrm{Ar}}\right), 7.50(\mathrm{br}$. $\mathrm{s}, 1 \mathrm{H}, \mathrm{NH}) .{ }^{13} \mathrm{C}-\mathrm{NMR}\left(\mathrm{DMSO}-\mathrm{d}_{6}, 100 \mathrm{MHz}\right) \delta: 113.46,113.92,114.01,115.51,117.32,118.66,119.41,119.72,123.55$, $123.94,125.67,128.88,129.03,129.32,129.40,131.08,131.27,131.23,137.18,137.84,146.30,146.59$. EI-MS $\left(\mathrm{C}_{32} \mathrm{H}_{26} \mathrm{~N}_{6}\right)$ : Calcd. (494); found molecular ion peak $494\left[\mathrm{M}^{+}\right]$.

\subsection{Textile Printing}

\subsubsection{Preparation of printing paste}

The paste used for application of the printing polyester fiber was shown in Table 5.

Table 5. The printing pastes composition

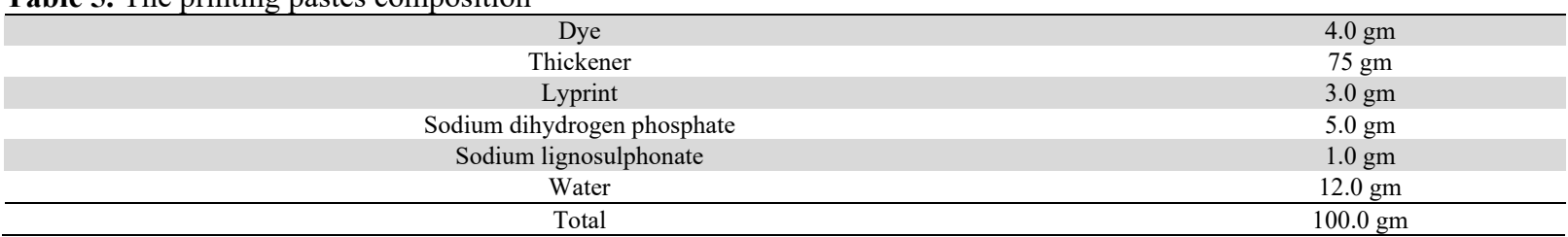

\subsubsection{Colour fastness tests}

Fastness properties including washing, perspiration, rubbing, light and sublimation of the dyed polyester fabrics were evaluated according to the standard ISO methods. ${ }^{23-27}$ 


\subsection{Determination of antibacterial activity}

The azo disperse dyes 8 (a-d), 10 (a, b), 12 and 14 were assayed in vitro for antibacterial activity against Gram $(+)$ bacteria called Staphylococcus aureus ATCC6538, Bacillus subtilis ATCC6633 and Streptococcus faecalis and Gram (-) bacteria called Escherichia coli ATCC8739, Pseudomonas aeruginosa ATCC9022 and Neisseria gonorrhoeae using the standard diffusion method. ${ }^{28}$

The bacterial strain was monitored by inoculation and incubation individually in to Lysogeny broth media for 24 hrs. at $35 \pm 2{ }^{\circ} \mathrm{C}$. Then in aseptic conditions, $100.0 \mu \mathrm{L}$ of each bacterial strain $(1 \times 108 \mathrm{CFU} / \mathrm{mL})$ was placed into petri dishes on Muller Hinton agar media. $1.0 \mathrm{~cm}^{2}$ of printed poly ester was applied to the steeded Muller Hinton agar plates and placed in the refrigerator for 24 hours before incubation at $352^{\circ} \mathrm{C}$ after incubation process, the diameters (inhibition zones (mm)) of each plate were observed around the fabric samples.

The antibacterial assay of each of loaded polyester fabrics were recorded after four washing cycles as the following treatments; (A) is Ampicillin (standard disc ,antibacterial agent) as positive control, (B) is the starting material 1 (9chloroacridine), (C) is the untreated polyester fabrics as negative control, (D) is the polyester fabrics which loaded with azo dyes $(\mathbf{8}(\mathbf{a}-\mathbf{d}), 10(\mathbf{a}, \mathbf{b}), 12$ and $\mathbf{1 4}) .^{29}$

The antibacterial activity was obtained as the following method, the tested bacteria $(100.0 \mu \mathrm{L})$ were grown in fresh media $(10.0 \mathrm{~mL})$ until they reached a count of approximately 108 cells $/ \mathrm{mL}$ for each bacteria ${ }^{30,31}$. The bacterial suspension $(100.0 \mu \mathrm{L})$ was spread on agar plates that matched the broth in which they were held. The isolated colonies of each organism that could be pathogenic should be chosen from primary agar plates and susceptibility checked using the disc diffusion process. ${ }^{32}$. Plates with Gram (+) and Gram (-) bacteria were incubated at $35-37^{\circ} \mathrm{C}$ for $(24-48 \mathrm{hrs}$.), while Candida albicans yeast was incubated at $30^{\circ} \mathrm{C}$ for (24-48 hrs.) (24-48 hrs.). The diameters of the inhibition zones were recorded in millimetres 29. The standard discs of reference drug (Ampicillin, antibacterial agent) were served as positive controls for antibacterial activity while filter discs which were impregnated in $10.0 \mu \mathrm{L}$ of solvent (deionized water, chloroform, DMSO) were used as a negative control. Blank paper disks (Schleicher \& Schuell, Spain) (a diameter $=8.0 \mathrm{~mm}$ ) were soaked in $10.0 \mu \mathrm{L}$ of the tested concentration of the stock solutions and placed on the agar. The chemical will diffuse from the disc into the agar only around the disc. The size of chemical infiltration around the disc will be determined by the chemical's solubility and molecular size. The area of no growth around the disc is the zone of inhibition or clear zone which was determined by placing organism on the agar and wasn't be grown in the area around the disc due to its sensitivity to the chemical. The zone diameters of the disc diffusion were determined using the slipping callipers of the National Committee for Clinical Laboratory Standards. ${ }^{30,31}$ The methods based on agar, such as E test and disc diffusion, can be good alternatives to brothbased methods because they are simpler and faster. ${ }^{33}$

\section{References}

1 Mahmoud W.H., Sayed, F.N., Mohamed, G.G. (2016) Synthesis, characterization and in vitro antimicrobial and antibreast cancer activity studies of metal complexes of novel pentadentate azo dye ligand. Appl. Organomet. Chem., 30 (11) 959-973.

2 Kantar C., Akal, H., Kaya, B., Islamoğlu, F., Türk, M., Şaşmaz, S. (2015) Novel phthalocyanines containing resorcinol azo dyes; synthesis, determination of $\mathrm{pKa}$ values, antioxidant, antibacterial and anticancer activity. J. Organomet. Chem., 783 28-39.

3 Ghasemi Z., Azizi, S., Salehi, R., Kafil, H.S. (2018) Synthesis of azo dyes possessing N-heterocycles and evaluation of their anticancer and antibacterial properties. Monatsh Chem Chem Mon., 149 (1) 149-157.

4 Saad F.A., El-Ghamry, H.A., Kassem, M.A., Khedr, A.M. (2019) Nano-synthesis, Biological Efficiency and DNA binding affinity of new homo-binuclear metal complexes with sulfa azo dye based ligand for further pharmaceutical applications. J Inorg Organomet Polym Mater., 29 (4) 1337-1348.

5 Muhammad-Ali M.A., Hamza Salman, H., Jasim, E. (2019) Antioxidant ac tivity of some newly prepared symmetrically azodyes derived from sulfa drugs . Asian J. Pharm. Clin. Res., 12 (2) 479-483.

6 Gouda M.A., Eldien, H.F., Girges, M.M., Berghot, M.A. (2016) Synthesis and antitumor evaluation of thiophene based azo dyes incorporating pyrazolone moiety. J. Saudi Chem. Soc., 20 (2) 151-157.

7 Kennedy D.A., Vembu, N., Fronczek, F.R., Devocelle, M. (2011) Synthesis of mutual azo prodrugs of anti-inflammatory agents and peptides facilitated by $\alpha$-aminoisobutyric acid. J. Org. Chem., 76 (23) 9641-7.

8 Wiley-VCH K.H. (2004) Industrial Dyes; Chemistry, Properties, Applications Edited by Klaus Hunger. Wiley-VCH: Weinheim. 2003. 660 pp. ISBN 3-527-30426-6. Org. Process Res. Dev., 8 (2) 296-297.

9 Benkhaya S., M'Rabet, S., El Harfi, A. (2020) Classifications, properties, recent synthesis and applications of azo dyes. Heliyon, 6 (1) e03271.

10 Finch C.A. (1986) Kirk-Othmer 'Concise encyclopedia of chemical technology'. Edited by M. Grayson, WileyInterscience, New York, 1985. ISBN 0-471-86977-5. J.Br. Polym., 18 (6) 400.

11 Timpe H.J. (1991) Photochromism - molecules and systems. Herausgeber: Dürr, H., Bouas-Laurent, H. 1. Auflage, 1068 S. Amsterdam, Oxford, New York, Tokyo: Elsevier, Schriftenreihe: Studies in organic chemistry, 40. ISBN 0-44487432-1. J. Prakt. Chem., 333 (5) 811-812. 
12 Langhals H. (2004) Color Chemistry. Synthesis, Properties and Applications of Organic Dyes and Pigments. 3rd revised edition. By Heinrich Zollinger. Angew. Chem., Int. Ed., 43 (40) 5291-5292.

13 Chen R., Huo, L., Jaiswal, Y., Huang, J., Zhong, Z., Zhong, J., Williams, L., Xia, X., Liang, Y., Yan, Z. (2019) Design, Synthesis, Antimicrobial, and Anticancer Activities of Acridine Thiosemicarbazides Derivatives. Molecules, 24 (11) 2065.

14 Fu W., Li, X., Lu, X., Zhang, L., Li, R., Zhang, N., Liu, S., Yang, X., Wang, Y., Zhao, Y., et al. (2017) A novel acridine derivative, LS-1-10 inhibits autophagic degradation and triggers apoptosis in colon cancer cells. Cell Death Dis., 8 (10) e3086.

15 Wang N., Świtalska, M., Wang, L., Shaban, E., Hossain, M.I., El Sayed, I.E.T., Wietrzyk, J., Inokuchi, T. (2019) Structural Modifications of Nature-Inspired Indoloquinolines: A Mini review of their potential antiproliferative activity. Molecules, 24 (11) 2121.

16 Zadafiya S.K., Tailor, J.H., Malik, G.M. (2013) Disperse dyes based on thiazole, their dyeing application on polyester fiber and their antimicrobial activity. J. Chem., 851418.

17 Jasiński R., Miroslaw, B., Demchuk, O., Babyuk, D., Łapczuk-Krygier, A. (2016) In the search for experimental and quantumchemical evidence for zwitterionic nature of (2E)-3-[4-(dimethylamino)phenyl]-2-nitroprop-2-enenitrile - An extreme example of donor- $\pi$-acceptor push-pull molecule. J. Mol. Struct., 1108 689-697.

18 Ibrahim N.A., Abo-Shosha, M.H., El-Zairy, E.A.M.R., El-Zairy, E.M. (2006) New thickening agents for reactive printing of cellulosic fabrics. Carbohydr. Polym., 101 (6) 4430-4439.

19 Benkhaya S., M' rabet, S., El Harfi, A. (2020) A review on classifications, recent synthesis and applications of textile dyes. Inorg. Chem. Commun., 115107891.

20 Ghorab M.M., Ragab, F.A., Heiba, H.I., El-Gazzar, M.G., Zahran, S.S. (2015) Synthesis, anticancer and radiosensitizing evaluation of some novel sulfonamide derivatives. Eur. J. Med. Chem., 92 682-692.

21 Molnar M., Harshad, B., Rastija, V., Pavić, V., Komar, M., Karnaš, M., Babic, J. (2018) Environmentally friendly approach to knoevenagel condensation of rhodanine in choline chloride: urea deep eutectic solvent and QSAR studies on their antioxidant activity. Molecules, 23 (8) 1897.

22 Karc1 F. (2005) Synthesis of disazo dyes derived from heterocyclic components. Color. Technol., 121 (5) $275-280$.

23 ISO 105-C06 Textiles: Tests for colour fastness., in Part C06: Colour fastness to domestic and commercial laundering. 2010. p. 9.

24 ISO 105-X12 Textiles: Tests for colour fastness. Part X12: Colour fastness to rubbing. 2016. p. 5.

25 ISO 105-E04:Textiles -Tests for colour fastness- Part E04: Colour fastness to perspiration. 2013. p. 5.

26 ISO 105-P01:Textiles -Tests for colour fastness- Part P01: Colour fastness to dry heat (excluding pressing). 1993. p. 3.

27 ISO 105-B02:Textiles -Tests for colour fastness-Part B02: Colour fastness to artificial light: Xenon arc fading lamp test. 2013. p. 35.

28 Balouiri M., Sadiki, M., Ibnsouda, S.K. (2016) Methods for in vitro evaluating antimicrobial activity: A review. J. Pharm. Anal., 6 (2) 71-79.

29 Mohmed A., Fouda, A., Abdel-Rahman, M., Hassan, S., Gamal, S., Salah Salem, S., Shaheen, T.I. (2019) Fungal strain impacts the shape, bioactivity and multifunctional properties of green synthesized zinc oxide nanoparticle. Biocatal. Agric. Biotechnol., 19101103.

30 Brown W.J. (1988) National Committee for Clinical Laboratory Standards agar dilution susceptibility testing of anaerobic gram-negative bacteria. Antimicrob Agents Chemother, 32 (3) 385.

31 Pfaller M.A., Burmeister, L., Bartlett, M.S., Rinaldi, M.G. (1988) Multicenter evaluation of four methods of yeast inoculum preparation. J Clin Microbiol, 26 (8) 1437-1441.

32 Kiehlbauch J.A., Hannett, G.E., Salfinger, M., Archinal, W., Monserrat, C., Carlyn, C. (2000) Use of the National Committee for Clinical Laboratory Standards guidelines for disk diffusion susceptibility testing in New York state laboratories. J Clin Microbiol, 38 (9) 3341-3348.

33 Fresco D., Coles, M., Heimberg, R.G., Liebowitz, M., Hami, S., Stein, M.B., Goetz, D. (2001) The liebowitz social anxiety scale: a comparison of the psychometric properties of self-report and clinician-administered formats. Psychol Med., 31(6) 1025-1035.

34 Laidlaw B. (1991) Standard methods for the determination of the colour fastness of textiles and leather, 5th edition (BS 1006:1990). J. Soc. Dye., 107 (2) 84.

35 Salami A.U., Kabir, Y.M., Ademola, B.K., Obinna, N.P., Ziyaei, H.A. (2020) Synthesis and dyeing performance of some amphiphilic naphthalimide azo disperse dyes on polyester fabrics. J. Serbian Chem. Soc., 85 (10) 1253-1264.

36 McLellan M.R., Lind, L.R., Kime, R.W. (1995) Hue angle determinations and statistical analysis for multiquadrant hunter L,a,b data. J. Food Qual., 18 (3) 235-240.

37 Rahman M.M., Haque, T.M.A., Sourav, N.S., Rahman, S., Yesmin, S., Mia, R., Al Noman, A., Begum, K. (2021) Synthesis and investigation of dyeing properties of 8-hydroxyquinoline-based azo dyes. J. Iran. Chem. Soc., 18 (4) $817-$ 826.

38 Mahmoud Elkholy Y., Helmy Helal, M., wahba Erian, A. (2001) Novel synthesis of thiazole disperse dye derivatives. Pigm resin technol, 30 (3) 168-171.

39 Patel D.M., Patel, T.S., Dixit, B.C. (2013) Synthesis, characterization and dyeing performance of new bisazobisazomethine disperse dyes. J. Saudi Chem. Soc., 17 (2) 203-209. 
40 Ketema A., Worku, A. (2020) Review on intermolecular forces between dyes used for polyester dyeing and polyester fiber. J. Chem., 7.

41 Al-Etaibi A.M., El-Apasery, M.A. (2020) A Comprehensive review on the synthesis and versatile Applications of biologically active pyridone-bBased disperse dyes. Int J Environ Res Public Health, 17 (13) 4714.

42 Otutu J.O., E.M, E., Ameru, S.U. (2014) Synthesis of disazo disperse dye compounds derived from 4- bromoaniline and 3-aminophenol as potential near infra-red absorbers. Chem. Mater., 6 (2) 40-46.

43 Salem S.S., Mohamed, A., El-Gamal, M., Talat, M., Fouda, A. (2019) Biological decolorization and degradation of azo dyes from textile wastewater effluent by aspergillus niger. EJCHEM., 62 (10) 1799-1813.

44 Alsharif S.M., Salem, S.S., Abdel-Rahman, M.A., Fouda, A., Eid, A.M., El-Din Hassan, S., Awad, M.A., Mohamed, A.A. (2020) Multifunctional properties of spherical silver nanoparticles fabricated by different microbial taxa. Heliyon, 6 (5) e03943.

45 Fouda A., Abdel-Maksoud, G., Abdel-Rahman, M.A., Eid, A.M., Barghoth, M.G., El-Sadany, M.A.-H. (2019) Monitoring the effect of biosynthesized nanoparticles against biodeterioration of cellulose-based materials by Aspergillus niger. Cellulose, 26 (11) 6583-6597.

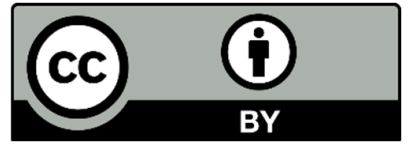

(C) 2022 by the authors; licensee Growing Science, Canada. This is an open access article distributed under the terms and conditions of the Creative Commons Attribution (CC-BY) license (http://creativecommons.org/licenses/by/4.0/). 